\title{
Water Project: Computer-Supported Collaborative E-Learning Model for Integrating Science and Social Studies
}

\author{
Jyoon Yoon \& Lynn Brice \\ University of Minnesota at Duluth, United States
}

\begin{abstract}
This article reports a qualitative study on computer-supported collaborative learning during a multidisciplinary education project on environment. The water project is designed to provide the elementary teacher candidates opportunities to explore issues related to water and find solutions to them through the Internet. As a production of the water project, they created posters and fliers in a photograph application to educate people regarding water issues and discussed how their creations affected people's awareness of water issues, using a web-discussion tool. The teacher candidates' reflections revealed that the water project was a meaningful e-learning activity to raise awareness of the global water issues and create an opportunity for them to share their learning, incorporating science and social studies. This water project provided a computer-supported collaborative e-learning model for integrating science and social studies.
\end{abstract}

Keywords: E-learning; Computer supported learning; Collaborative learning; Integrated education; Science education; Social studies

\section{Introduction}

\section{Integration of Science and Social Studies Education}

An important purpose of science education is to give students a means of understanding and acting on social issues and develop decision-making skills. The social perspectives to science give students a foundation on which to base decisions they will face as citizens (National Committee on Science Education Standards and Assessment, 1996).

However, the social perspectives to science are complicated. The content is science and, to some extent, effects of social activities, relating to the nature of the social science world. Besides, the social perspectives to science are constantly evolving, and can never be presumed to be complete because it is involved by persistent historical debates relating to social sciences and humanities in the society.

To analyze and explain social issues and perspectives to science, science classrooms need to facilitate time and space to share continuously sociological knowledge, sociological theory and issues. Computer-supported collaborative learning $(\mathrm{CSCL})$ meets the need of the science 
classrooms wherein learning takes place via social interaction using a computer or through the Internet (Stahl, 2006). The learning in CSCL is characterized by the sharing and construction of knowledge among participants using technology as their primary means of communication or as a common resource. The CSCL can be implemented in online and classroom learning environments and can take place synchronously or asynchronously.

\section{Computer-Supported Collaborative E-Learning Model}

The Computer-Supported Collaborative E-Learning ( $\mathrm{CSCL}$ ) is one of the most innovative e-learning to improve teaching and learning with the help of modern information and communication technology. CSCL is designed to encourage or require students to work together on learning tasks. The collaborative learning is distinguished from the traditional direct transfer model in which the instructor is assumed to be the distributor of knowledge and skills.

The CSCL draws on a number of academic disciplines, including instructional technology, sociology, educational psychology, and social psychology (Hmelo-Silver, 2006). The rapid development of social media technologies and the increasing need of individuals to understand and use those technologies have brought researchers from many disciplines to the field of CSCL. A computer supported environment allows space for bringing different points of view and resources together to create communities in which social debate and critique, discussion and reflection, as well as collaborative knowledge construction can lead to new insights, new ideas, and new artifacts.

Koschmann (2002) defines CSCL as "a field centrally concerned with meaning and practices of meaning-making in the context of joint activity and the ways in which these practices are mediated through designed artifacts" (p.18). Two critical elements in CSCL are collaborative learning and computer-support. CSCL is concerned with collaborative-meaning making processes that go beyond information sharing among multiple people. Technology such as computers can play a critical role to support or mediate the interactive process of collaborative meaning making in the context of joint activities involving multiple users and multiple modes of interaction.

The case study of Ma (2008) resulted that CSCL built up the supportive and collegial interpersonal relationships to encourage open negotiation and argumentation in creative dialogues. The participants of the case study were undergraduate students who were assigned to complete a fashion design project in groups. This study provided that the CSCL promoted re-design and cocreation of new fashion design.

Ma's study showed the typical model for CSCL research studies. The online messages posted by the students were collected and analyzed for measuring the effectiveness of CSCL. The analysis of the online postings was carried out first at the message level and then categorized according to different aspects to be evaluated. For the study, basic knowledge of fashion design and use of Photoshop to illustrate fashion sketches were conducted face-to-face. Web-based tools allowed users to quickly and easily add or find digital representations of cultural products, comment them with peer critiques, redesign them with new meanings, and distribute their work via the asynchronous medium. This free association of ideas through CSCL provided a useful lens for understanding the creative process in online communities of cultural production. 
According to Yoon (2007), CSCL was useful to solve a problem and develop a lesson. Her research study was with teacher candidates who were given to read articles about educational behaviorism and plan a lesson that gets their students actively involved in. The teacher candidates made groups and posted their ideas on the online discussion tool after they read the articles. Based on the posted messages, each group collaboratively worked on a lesson. Compared with other groups who did not use the collaborative web-posting, the experimental groups were highly scored in understanding the questions, developing lessons, being creative, and functioning their roles properly.

$\mathrm{CSCL}$ differs from traditional types of learning. In CSCL, the contents and outcomes of learning are not merely knowledge in texts and the heads of students but new forms of practical activity and artifacts constructed by students in the process of tackling real-life projects or problems. Learning is driven by genuine developmental needs in human practices and institutions, confirmed in disturbances, breakdowns, problems, and episodes of questioning the existing practice. The learning proceeds through complex cycles of learning actions in which new objects and motives are created and implemented, opening up wider possibilities for participants involved in that activity. CSCL highlights the potential impact of social community through computers as vehicles for transforming activity procedures.

\section{Social Creativity Development}

The concept of environmental justice or ecojustice framed this project. Ecojustice is concerned with redressing inequitable distribution and consumption of resources as well as distribution of environmental burdens (Wenden, 2004). Ecojustice is ultimately concerned with all people reaching their highest potential, which requires healthy communities. Healthy communities require clean, safe environments, and the political and economic resources to achieve and maintain them. Within the framework of ecojustice adopted for the project, the concept of the commons was central. The commons is an ancient idea across the globe. It is the idea that the natural world and its resources belong to no one yet they are communal and their care is a shared, communal responsibility.

A primary concern of this project is to educate people for creating an informed citizenry that acts to address the needs and issues of its communities, local and global. As Dewey (1916) noted, engagement in the activities of a concerned citizenry happens in the small spheres of social life, as well as the grand. Advocacy and activism can happen in small, simple ways that move others to think and act. This water project provided a context through which teacher candidates explored curriculum model integrating science and social studies with aids of technology, focused on raising awareness of both local water issues and the global crisis over water. The teacher candidates created art disruptions in the form of posters and fliers to draw attention to the crisis and persuade viewers to act.

To develop the art disruptions, the teacher candidates made groups where creativity development is viewed as a transactional process that involves active transformation of individual, environment, and the socio-cultural world (Artman, et al, 2005). Creativity development involves the 
transformation of the individual in relation to the contexts through which the individual transformation is realized. It is creativity that is based in systemic dynamics. It is creativity that is sustained and distributed in nature, which does not reside in a single cognitive or personality process, does not occur at any single point in time, does not happen at any particular place, and is not the product of a single individual. In this manner, creativity is a social entity, one that is both socially produced and socially validated (Dewey, 1916). This conception of social creativity development is adopted for this study as it resonates highly with CSCL.

The processes for the social creativity development in CSCL occur in a set of three phases (Artman, et al, 2005):

Phase I: Exploration/clarification - understanding of the reasoning behind design proposals and choices.

Phase II: Negotiation and argumentation - engagement in making meanings through a process of capture, manipulation, and transformation of media by means of social debate, critique, and discussion. It is the confrontation and combination of divergent perspectives among social community.

Phase III: Evidence of evolution and redesign - modification of artifacts, synthesis of diversity of perspectives, exploitation and building on the multiple voicedness of the past, emerging from exchanges with knowledgeable peers and mentors, leading to convergence among the social community.

These phases may occur in any order and may repeat in an iterative cycle. In phase III, redesigned artifacts are externalized for the peer critique that will start over the cycle again. The final stage will be the dissemination of shared understanding comprising of co-design of artifacts and cocreation of new insights, new knowledge, and new understanding.

The speed and range of communication technology promote the processes for the social creativity development. In CSCL, students enable to collaborate with others in immediate and dynamic ways during their creative work in progress. CSCL supports asynchronous, networked brainstorming, eliminating the time and space restrictions. Collaboration with artists, writers, and professionals in non-residence through email or video conferences offers students opportunities to work with knowledgeable and creative others to generate ideas, pursue purpose as well as evaluate ongoing and original work (Loveless, 2002).

The creative processes are further supported by the immediacy of the presentation, the ease of manipulation, and the possibilities of tracing the development of ideas or revisiting them in order to explore other possible routes. Collaboration in such an intrinsic rewarding environment is perceived as a significant contribution of CSCL to foster creativity. Increased autonomy experienced in online communities of CSCL also gives a sense of freedom to explore and play within the community in a reduced risk environment. 


\section{Purpose of the Project}

With reference to the existing CSCL studies, the Water Project was designed in the present study to provide the elementary teacher candidates opportunities to explore issues and solutions related to water through the Internet and create art disruptions in the form of poster and flier. The teacher candidates could understand science in the context of computer supported collaborations, which could develop an environment to integrate science and social studies by bringing different points of view and resources together to create social communities. Further, this provided the teacher candidates to develop a means that helps their students to understand and act science on social issues and develop decision-making skills as citizens.

\section{Methodology}

\section{Subjects}

Thirty elementary teacher candidates participated in this water project. They were in the second semester of the elementary teacher license program. In the first semester, they learned how to teach language art and math. In the second semester, they had method courses of science, social studies, Indian studies, and special education. The teacher candidates in the second semester had 8 weeks of classroom learning and 8 weeks of teaching practicum in the field. This water project was a part of the science and the social studies method course before they went to practice teaching in the field.

\section{Water Project}

This water project was designed for the teacher candidates to: (1) become aware of and potentially involved in water issues; (2) explore teaching methods in computer-supported collaborative e-learning; (3) explore a model of inquiry and action that weaves together science and social studies curriculum, conceptions of eco-justice and theories of the commons, and artsbased public engagement; and (4) think creatively about the world around them and get involving community.

The water project was for a week. First, the teacher candidates were assigned to read Great Lakes: Sewage Report Card (Sierra Legal Report, 2006). This report represents the analysis of municipal sewage treatment and discharge into the Great Lakes basin. In the report, the great concern is combined sewer overflows and the release of raw sewage into the Great Lakes.

After reading about the report, the teacher candidates had a time to be introduced to Lake Superior, one of the Great Lakes, by a professional from the community Lake Superior research center. The professional talked about the current issues with the Lake Superior: (1) Overfishing; (2) Nutrient Loading; (3) Toxic Chemicals; (4) Hydrologic Alterations; (5) Land use/Changes; (6) Invasive Species; and (7) Climate Change. After the presentation of the professional, the teacher candidates had a time to discuss about the issues of Lake Superior in the class. This interaction 
with the professional promoted the teacher candidates to understand the importance of water protection and get more information about how to protect water.

The complement to teacher candidates' engagement with the politics and science of Lake Superior and the global water crisis was the opportunity to explore the aesthetic relationships we as humans have with water through an Ojibwe (one of the largest native American groups) worldview. The teacher candidates worked with another guest instructor who was a master speaker and teacher of Ojibwe language and culture, who shared an understanding of the cultural and spiritual meaning of water.

Through the National Science Education Standards, the teacher candidates understood that it is science in social perspectives to learn about the issues of Lake Superior and find solutions. This water project provided opportunities for the teacher candidates to understand the various scientific situations when they face regarding the water issues in the future and make better decisions as citizen in the society.

Technology assisted the teacher candidates to understand and progress the water project. Through web-searching, they could find out global water issues and solutions. The teacher candidates produced ideas of how to protect the Lake Superior: (1) Using environmentally friendly alternatives; (2) Building hazardous water disposal centers; and (3) Developing environmental protection laws. They shared them through the online discussion tools (emails, online-chat tools, and Moodle discussion). Photographic application using images, information, quotes etc., fostered the teacher candidates to create posters and fliers for sharing with the audience an important consideration of water issues or simply a persuasion about water.

The posters and the fliers are the final artifacts to disrupt the audience's routine for just a moment to give them pause to think about water, what it means in their lives, and what it would mean to consume water out of the limited resources. The fliers and posters depicted images and information about the state of water in the Great Lakes, with the intention of disrupting viewers' routines. For example, as a person went to a drinking fountain, he was interrupted by a compelling flier and given pause to think about water. As art disruptions, the posters and fliers were posted around the college near water fountains, water coolers, sinks, bathrooms, as well as general areas of public.

The researcher developed a website that provides a direction for the teacher candidates to follow with. The website included the article of Great Lakes: Sewage Report Card, goals, procedure, and assignments of the water project.

\section{Data Gathering}

After this water project, the teacher candidates in groups were assigned to submit (1) their poster/flier and a worksheet and (2) a short reflection paper. The poster/flier and the worksheet were handed in together and the worksheet needed to include: 
A. Description of the Message: Describe (a) what the water issue is in the poster/flier; (b) Provide what the impact of the water problem is in society; and (c) Identify other environmental problems contributing to or developing from the water issue.

B. Map: Map out the hot spots (globally) where the water issue has its greatest effects.

C. Controversy and Solutions: (a) Explain the various controversies associated with the water issue; (b) Describe the interest groups or stakeholders involved; and (c) Provide possible solutions or ways to combat the water problem.

D. Resources and Citations: Use a variety of resources, print and electronic. Recent developments on the water issue can be searched through newspaper articles and Internet. Use at least two print materials and one Internet site. Apply appropriate referencing throughout the poster.

Table 1 shows the rubric to evaluate the teacher candidates' final artifacts, poster/flier and the worksheet, in performance and written format. The performance is the method how the teacher candidates present their poster/flier, for example, a PowerPoint presentation, a song for the poster/flier, and a play related to a water issue. The performance and the writing need to have exemplary and professional appearance, sending appropriate message and dominating slogan. Also, their performance provides right amount of information (not too much or too little to be convincing) with a balance between art and science. The audience is able to follow the information that is delivered from the poster/flier. Further, the performance and writing need to be unique, clever, and exciting to see/read.

The teacher candidates were also assigned to write a short paper ( $1 \frac{1 / 2}{2}-2$ pages) on the online discussion tool, reflecting upon global water issues and interdisciplinary approaches that they applied to the water project.

Table 1. Rubric for Evaluating Poster and Worksheet

\begin{tabular}{|c|c|c|c|c|c|}
\hline Category & $10-8$ & $8-6$ & 6- 3 & $3-1$ & 0 \\
\hline $\begin{array}{l}\text { Originality \& } \\
\text { Bibliography }\end{array}$ & $\begin{array}{l}\text { All sources used } \\
\text { to create } \\
\text { performance/writ } \\
\text { ing are original } \\
\text { and have been } \\
\text { properly cited. }\end{array}$ & $\begin{array}{l}\text { All sources used } \\
\text { to create } \\
\text { performance/w } \\
\text { riting are cited, } \\
\text { but not in } \\
\text { correct format. }\end{array}$ & $\begin{array}{l}\text { Some sources are } \\
\text { original and } \\
\text { related to the } \\
\text { issue. Citations } \\
\text { for sources may } \\
\text { be missing. }\end{array}$ & $\begin{array}{l}\text { Sources are not } \\
\text { original or no } \\
\text { sources have } \\
\text { been cited. }\end{array}$ & $\begin{array}{l}\text { All the sources } \\
\text { are not original } \\
\text { and no resources } \\
\text { have been cited. }\end{array}$ \\
\hline Mechanics & $\begin{array}{l}\text { Performance and } \\
\text { the writing have } \\
\text { exemplary and } \\
\text { professional } \\
\text { appearance. } \\
\text { Sending } \\
\text { appropriate } \\
\text { message. } \\
\text { Dominate slogan. }\end{array}$ & $\begin{array}{l}\text { Performance } \\
\text { and the writing } \\
\text { have } \\
\text { professional } \\
\text { appearance. } \\
\text { Appropriate } \\
\text { message. } \\
\text { Appropriate } \\
\text { amount of }\end{array}$ & $\begin{array}{l}\text { Performance and } \\
\text { the writing have } \\
\text { appropriate } \\
\text { message but } \\
\text { poorly presented. } \\
\text { The performance } \\
\text { is workable but } \\
\text { sometimes the } \\
\text { information does }\end{array}$ & $\begin{array}{l}\text { Poor } \\
\text { appearance. } \\
\text { Disorganized, } \\
\text { loses focus, or } \\
\text { may be hard to } \\
\text { follow. Word } \\
\text { choices are } \\
\text { incorrect in the } \\
\text { way the words }\end{array}$ & $\begin{array}{l}\text { The performance } \\
\text { and the writing } \\
\text { are not properly } \\
\text { presented in } \\
\text { appearance and } \\
\text { message. }\end{array}$ \\
\hline
\end{tabular}




\begin{tabular}{|c|c|c|c|c|c|}
\hline & $\begin{array}{l}\text { Performance } \\
\text { provides right } \\
\text { amount of } \\
\text { information (not } \\
\text { too much or too } \\
\text { little to be } \\
\text { convincing) with } \\
\text { a balance } \\
\text { between art and } \\
\text { science. } \\
\text { Information is } \\
\text { easy to follow. } \\
\text { Performance and } \\
\text { writing are } \\
\text { unique, clever, } \\
\text { and exciting to } \\
\text { see/read. }\end{array}$ & $\begin{array}{l}\text { information } \\
\text { (balance } \\
\text { between } \\
\text { science and } \\
\text { art). } \\
\text { Appropriate to } \\
\text { the message } \\
\text { and clear } \\
\text { message. }\end{array}$ & $\begin{array}{l}\text { not flow. The } \\
\text { word choices do } \\
\text { not enhance the } \\
\text { persuasiveness of } \\
\text { the campaign. }\end{array}$ & $\begin{array}{l}\text { are used, do not } \\
\text { make sense, or } \\
\text { are } \\
\text { inappropriate } \\
\text { for the topic. }\end{array}$ & \\
\hline Content & $\begin{array}{l}\text { Covers the issue } \\
\text { in-depth with } \\
\text { details and } \\
\text { examples. The } \\
\text { issue information } \\
\text { is excellent. More } \\
\text { than three facts } \\
\text { have been sent } \\
\text { about the } \\
\text { problem. } \\
\text { Masterfully } \\
\text { related to the } \\
\text { issue. }\end{array}$ & $\begin{array}{l}\text { Include } \\
\text { essential } \\
\text { knowledge } \\
\text { about the issue. } \\
\text { The issue } \\
\text { information } \\
\text { appears to be } \\
\text { good (three } \\
\text { facts about the } \\
\text { problem). }\end{array}$ & $\begin{array}{l}\text { Include essential } \\
\text { knowledge about } \\
\text { the issue but } \\
\text { there are } 1-2 \\
\text { factual errors or } \\
\text { only } 2 \text { facts listed. }\end{array}$ & $\begin{array}{l}\text { Content is } \\
\text { minimal or } \\
\text { there are more } \\
\text { than } 2 \text { factual } \\
\text { errors. Only } 1 \\
\text { fact listed. }\end{array}$ & $\begin{array}{l}\text { No fact about } \\
\text { the issue. }\end{array}$ \\
\hline Workload & $\begin{array}{l}\text { The workload is } \\
\text { divided and } \\
\text { shared equally by } \\
\text { all team } \\
\text { members. }\end{array}$ & $\begin{array}{l}\text { The workload is } \\
\text { divided and } \\
\text { shared fairly by } \\
\text { all team } \\
\text { members, } \\
\text { though } \\
\text { workloads may } \\
\text { vary from } \\
\text { person to } \\
\text { person. }\end{array}$ & $\begin{array}{l}\text { The workload } \\
\text { was divided, but } \\
\text { one person in the } \\
\text { group is viewed } \\
\text { as not doing } \\
\text { his/her fair share } \\
\text { of the work. }\end{array}$ & $\begin{array}{l}\text { The workload } \\
\text { was not divided } \\
\text { or several } \\
\text { people in the } \\
\text { group are } \\
\text { viewed as not } \\
\text { doing their fair } \\
\text { share of the } \\
\text { work. }\end{array}$ & $\begin{array}{l}\text { The work load } \\
\text { was not divided } \\
\text { and all the } \\
\text { people in the } \\
\text { group are viewed } \\
\text { as not doing } \\
\text { their fair share of } \\
\text { the work. }\end{array}$ \\
\hline Requirements & $\begin{array}{l}\text { All the } \\
\text { requirements are } \\
\text { met and } \\
\text { excellently } \\
\text { presented. }\end{array}$ & $\begin{array}{l}\text { One } \\
\text { requirement is } \\
\text { not met. }\end{array}$ & $\begin{array}{l}\text { Two } \\
\text { requirements are } \\
\text { not completely } \\
\text { met. }\end{array}$ & $\begin{array}{l}\text { More than two } \\
\text { requirements } \\
\text { are not } \\
\text { completely met. }\end{array}$ & $\begin{array}{l}\text { No requirements } \\
\text { met. }\end{array}$ \\
\hline
\end{tabular}




\section{Findings}

This study used qualitative data analysis. The teacher candidates explored social water issues and developed their final artifacts, poster/fliers and reflection through the collaborative creative processes in CSCL. The researcher built a holistic website with descriptions and pictures to guide the teacher candidates to complete the water project, conducted the study in a natural setting for duration of a week, monitored detailed views of the teacher candidates, and analyzed their final artifacts.

Different from Ma's case study and Yoon's study, the data from the teacher candidates were the final products, poster/flier and written reflection. Ma (2008) and Yoon (2007) measured the effectiveness of CSCL by analyzing the online messages posted by the participants all through the phases of the collaborative creative processes: Phase I- Exploration/clarification, Phase IINegotiation and argumentation, and Phase III- Evidence of evolution and redesign. However, in this water project, the teacher candidates submitted their final version poster/flier and reflections after online discussions done among members. They exchanged ideas and information over the online discussion tools with knowledgeable peers and mentors, modified their artifacts, synthesized diverse perspectives, and shaped up the final products. Besides, their poster/flier and final reflections were required to include the components to show the collaborative creative procedures and their feelings about this project, for example, water issues, map, controversy and solutions among the members. The crystallized final artifacts clearly showed their social activities through CSCL environment.

Figure 1 presents the poster from one of the teacher candidates' groups and the following is their worksheet:

\section{Water Project Worksheet}

A. Description of the Message: (1) What is the water issue? (2) What is the impact of the water problem on our society? (3) Identify other environmental problems contributing to or developing from the water issue.

(1) The water issue in our posters is the lack of safe, drinkable water in our world.

(2) Due to pollution of our world's water many people around the world do not have access to clean drinkable water. Eighty percent of deaths in the world are caused by consumption of polluted water. For example, $1 / 3^{\text {rd }}$ of the population in our world is in the countries of India and China; however these counties only have access to $1 / 10^{\text {th }}$ of our world's fresh water.

(3) The environmental problems stem from pollution of the small amount of fresh, usable water that people on our Earth actually have access to. The major sources of water pollution can be classified in three categories: municipal (home and commercial water waste), industrial (factories), and agricultural (fertilizer waste, pesticides, farming). 
B. Map: Map out the hot spots (globally) where your water issue has its greatest effects.

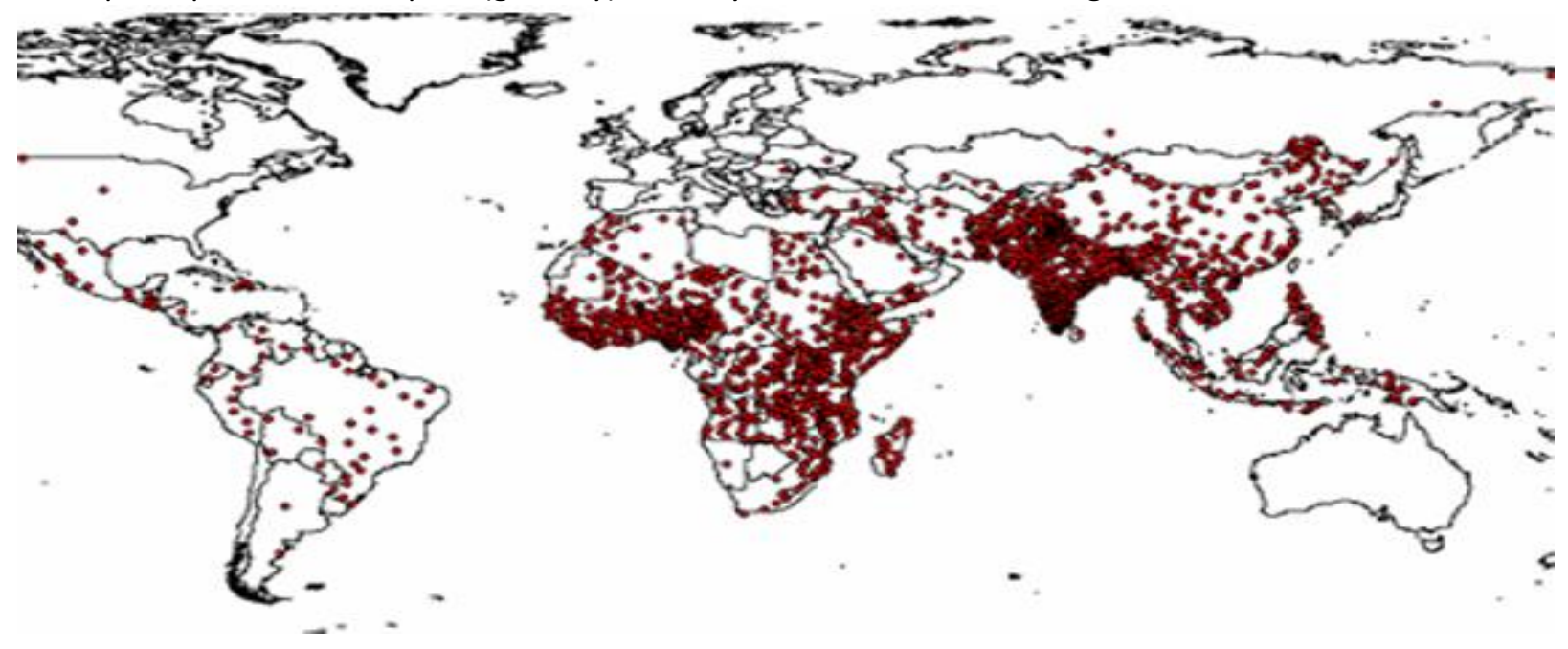

The red dots on the map indicate the locations in the world which are in most need of water. Africa and India show the highest concentration of people without clean water. (Education USA, 2009)

C. Controversy and Solutions: (1) Explain the various controversies associated with your water issue. (2) Who are the interest groups or stakeholders involved? What is the position of each group? (3) Are there possible solutions or ways to combat the water problem?

How much does global clean water actually cost? The major countries in the world are the stakeholders because they control who pays for the clean water of less fortunate countries. We all know that everyone needs safe water in order to live a long, healthy life. However, who is going to be paying for the water of less fortunate countries is the controversy at hand? The solution to the problem lies in the hands of every person in this planet who uses water; EVERYONE! We need to be conscious of our water use and recognize that water is a limited resource.

\section{Resources and Citations:}

Education USA. (2009). Retrieved 2010, 20-October from Heart for the Nations: http://www.heartforthenations.net/haiti.html

David Krantz, B. K. (1999). University of Michigan. Retrieved 2010 иил 20-October from Water Pollution and Society: http://www.umich.edu/ gs265/society/waterpollution.htm Hagley, C. (2010, 18-October). Sea Grant. (B. II, Interviewer)

Rochelle Strauss, R. W. (2007). One Well: The Story of Water on Earth. Toronto: Kids Can Press. 


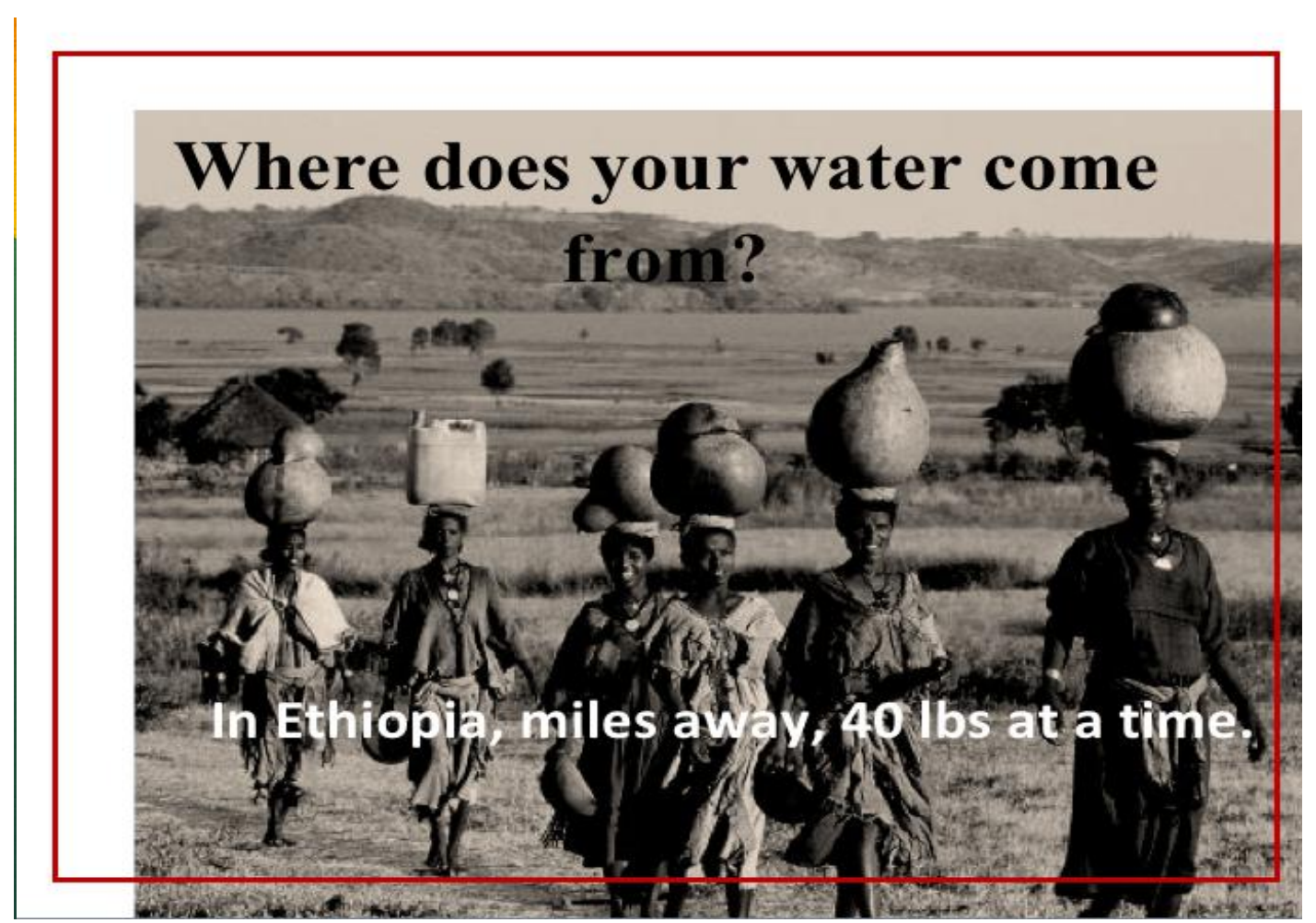

Figure 1. Student Poster of the Water Project, modified from Water Encyclopedia [Photograph] (2010)

$* * * * * * * * * * * * * * * * * * * * * * * * * * * * * * * * * * * * * * * * * * * * * * * * * * * * * * * * * * * * * * * * * * * * * * * * * * *$

This worksheet explained that the teacher candidates found the lack of safe and drinkable water as a global issue. Through web-searching, the teacher candidates knew how the water issue is serious and how much it affects globally. Also, they discussed controversies of water issues and solutions both over online discussion tools and at face-to-face meetings. Their poster delineated their ideas and the procedures all through the project.

The teacher candidates were also asked to reflect upon global water issues and interdisciplinary approaches that they applied to the water project. The following are the some reflections from the teacher candidates:

"I thought that making the posters as a form of disruption was a powerful activity. Raising awareness is a first step to creating a solution to a global problem, and it's a meaningful activity to let students be part of that."

"It is great to be able to disrupt the flow of a person's day and grab his attention with the posters we made. This assignment was not simply about how water can affect the world. As a student, I got to learn about an issue and what I can do to take action in my own school." 
"It was interesting to talk about possible actions we could take and then we actually engaged in the action. By making the posters, I think people around the school will be surprised at what is happening around the world and even locally with water. Through artistic disruption we will hopefully get people to think about what they can do to protect our sacred water."

"I learned about Lake Superior and how important it is. I was reminded about water pollution and how much water is wasted every day. I never realized how many people are in need of fresh water, and how many people suffer and die because they don't have the water that they need to survive. I thought it was really interesting to see from a Native American's point of view of what water means to their culture. I really did learn a lot about water but most of all I learned to be an advocate to help save water. I think I needed an experience like this to really get me thinking about an issue."

"I think this opened a lot of our eyes on how valuable water is to us. We don't think about it but when the water is gone, there is no way to get it back."

"I have always really appreciated and enjoyed water but never saw it in a larger context and saw its importance to others beyond myself. From this new understanding of water, it was easy to create a disruptive art piece- in this case a poster to remind the general public about the accessibility to clean water we enjoy in America."

Many of the teacher candidates realized how the water issue was globally serious after this water project. Through web-searching and online discussion, they could found water issues and solutions in the large context, shared ideas about water, and designed/redressed poster/flier. Especially, one of the reflections is talking about the social community where they talked about possible actions and then actually engaged in the action. The interactive process of collaborative creativity development co-created and re-designed their poster/flier with a meaning of artistic disruption. The posters and fliers that they produced interrupted the general public to think about water and other related issues.

\section{Conclusions}

Through this water project, the teacher candidates were able to be aware of and actively involved in water-related issues, explore computer-supported collaborative e-learning as teaching method, integrate science and social studies curriculum, conceptions of eco-justice and theories of the commons, and arts-based public engagement, and think creatively about the world around them and get involving community.

The results of the reflections indicated that the water project was an engaging model of the computer supported collaborative e-learning. By browsing the Internet and meeting community professionals, the groups of teacher candidates could see the whole picture of water issues in the global society. Also, by creating and hanging posters and fliers, they could have opportunities to apply to and share their learning with community. 
This project lasted only for a week and, even in the short amount of time, the teacher candidates got information about water in our local and global society and had a chance to share their learning not only with the class but also the whole community. All these were possible by using technology. The Internet made the teacher candidates able to search water, social issues of water, and solutions to them. The online-discussion tool was for the teacher candidates to share and exchange their ideas with others. The photographic applications assisted to create fliers and posters as art disruptions. Thus, the water project was helpful for the teacher candidates to produce chances fully to understand science in social context.

For further study, the water project can be in diverse formats of disruptive art (poster, music, play, movie, and so on) supported by computer technology. The information that could be added to the disruptive art can be even abundant provided by employing more tools, like meeting professionals through Skype, watching movie clips on YouTube, and so on. Interviewing with the general public who experience the disruptive art as a product of the water project can be included to measure how effectively the messages will be delivered.

\section{References}

Artman, H., Ramberg, R., Sundholm, H., \& C-Pargman, T. (2005). Action context and target context representations: A case study on collaborative design learning. In T. Koschman, D. Suthers, \& T. W. Chan (Eds.), Computer supported collaborative learning: The next 10 years! Mahwah, NJ: Lawrence Erlbaum Associates.

Dewey, J. (1916). Democracy and education. New York: Macmillan.

Hmelo-Silver, C.E. (2006). Analyzing collaborative learning: Multiple approaches to understanding processes and outcomes. Proceedings of the 7th International Conference on Learning Sciences (pp.1059-1065). USA.

Koschmann, T. (2002). Dewey's contribution to the foundations of CSCL research. Paper presented at the Computer Support for Collaborative Learning Conference. Boulder, CO.

Loveless, A. (2002). A literature review in creativity, new technology and learning: A report for NESTA Future lab. Retrieved on 7 July 2011 from http://www.nestafuturelab.org.uk

National Committee on Science Education Standards and Assessment. (1996). National Science Education Standards (pp.103-105). National Academies Press.

Ma, A. (2008). Computer supported collaborative learning and social creativity: A case study of fashion design. Journal of Information, Information Technology, and Organizations, 3.

Sierra Legal Report. (2006). The Great Lakes Sewage Report Card. Retrieved on 30 June 2011 from http://www.ecojustice.ca/publications/reports/the-great-lakes-sewage-report-card/ attachment

Stahl, G., Koschmann, T., \& Suthers, D. (2006). Computer-supported collaborative learning: An historical perspective. In R. K. Sawyer (Ed.), Cambridge handbook of the learning sciences, (pp.409-426). Cambridge, UK: Cambridge University Press. 
Water Encyclopedia [Photograph]. (2010). Retrieved 20 October 2010 from http://www. waterencyclopedia.com/Da-En/Developing-Countries-Issues-in.html

Wenden, A. (2004). Educating for a culture of social and economical peace. New York: SUNY Press.

Yoon, S. (2007). The effect of shared-leadership and questioning scaffolding on collaborative problem solving in CSCL. Korean Journal of Education Research, 45(4), 115-144.

Correspondence: Jyoon Yoon, Department of Education, University of Minnesota, Duluth, Minnesota, United States 